\title{
Hepatitis C and hepatitis B virus infections in the etiopathogenesis of pemphigus
}

\author{
Gulsen Tukenmez Demirci ${ }^{1}$ \\ Ayse Tulin Mansur ${ }^{3}$ \\ Ilknur Kivanc Altunay ${ }^{5}$
}

\author{
Ikbal Esen Aydingoz \\ Guldehan Atis ${ }^{4}$
}

\begin{abstract}
BACKGROUND: Previous studies have shown that some viral infections may be triggers for autoimmune diseases. The role of viral infections in the etiopathogenesis of pemphigus has also been investigated.

OвлестіvEs: To investigate the relationship between pemphigus and the hepatitis B and C virus infections.

METHODS: This retrospective study included 62 patients with pemphigus and 50 healthy controls of matching ages and genders. The control group included relatives who accompanied the orthopedic patients to the hospital but had no history of systemic and/or autoimmune diseases.

RESULTS: The group of patients with pemphigus was composed of $43(69.3 \%)$ females and $19(29.7 \%)$ males, and the mean age was $48.08 \pm 15.38$. The hepatitis $C$ virus antibody was negative in all of the patients. Hepatitis $B$ surface antigen (HBsAg), hepatitis B surface antibody (HBsAb), or both, were studied in 44 of the 62 patients. Two (4.3\%) of these patients were positive for HBsAg and found to have HBV infection. Fourteen of them were HBsAb positive. Two (4\%) of the 50 control subjects showed hepatitis C virus antibody positivity, while only $1(2 \%)$ patient with pemphigus displayed HBsAg positivity. There was no statistically significant difference between the two groups for hepatitis B and C virus infections.

ConClusions: This study does not support an association between pemphigus and hepatitis B and/or $\mathrm{C}$ virus infections.
\end{abstract}

Keywords: Hepatitis B vírus; Hepatitis antibodies; Pemphigus

\section{INTRODUCTION}

Pemphigus is a rare autoimmune disease of the skin and mucous membranes. Previous studies have shown that some viral infections may be triggers for autoimmune diseases in patients with genetic susceptibility to them. ${ }^{1}$ The role of viral infections in the etiopathogenesis of pemphigus has also been investigated. ${ }^{2}$ The role of HCV in the etiopathogenesis of secondary anti-phospholipid syndrome, Sjögren syndrome, autoimmune trombocytic purpura and cryoglobulinemia, have been reported. ${ }^{3,4}$ Similarly, the mechanisms involved in HBV infection have been proposed as a trigger in some autoimmune diseases such as diabetes mellitus type 1 , polyarteritis nodosa and vitiligo. ${ }^{56,7}$ However, there are few studies that evaluate the relationship between pemphigus and $\mathrm{HCV}$ and $\mathrm{HBV}$ infections. ${ }^{8-11}$ The purpose of this study is to investigate the frequency of $\mathrm{HCV}$ and HBV infections in our patients who had recently been diagnosed with pemphigus. 


\section{MATERIALS AND METHODS}

Sixty-two patients with a new diagnosis of pemphigus were included in this retrospective study. In addition to clinical and histopathological findings, diagnosis of pemphigus had been confirmed through direct immunofluorescent microscopy. The control group was composed of 50 subjects of matching ages and genders, gathered from among the relatives of the orthopedic patients. The controls all had a negative history for systemic and/or autoimmune diseases and had provided verbal informed consent for the study. In our departments, all patients with pemphigus are screened for HBsAg, HBsAb and anti-HCV, using ELISA, before starting appropriate immunosuppressive therapy, since this treatment can exacerbate viral infections such as HBV and HCV infections. The control group was set up after the decision had been taken to conduct a retrospective study. This group was informed about viral hepatitis and the vaccination for $\mathrm{HBV}$, and those who were found to be eligible for the study were included. The study used their patient records or face-to face interviews to obtain their ages, genders, serologic test results, family history of HBV and HCV occurrences and the risk factors for HBV and HCV infections, such as blood transfusion, hemodialysis, past operations, transplantation, ear piercing, dental surgery and similar trauma histories. The serological test results of pemphigus patients were acquired from the database of our patients' records.

\section{Statistical Analysis:}

SPSS Statistics 17.0 for Windows was used for statistical analysis. The distribution of the data was tested using Kolmogrov-Smirnov and Anova tests. The independent test was used for the analysis of the data; $p<0.05$ was considered to be significant.

\section{RESULTS}

The study group involved 62 pemphigus patients, including 43 women and 19 men (age range: $10-78$ years, mean $48.08 \pm 15.38$ ) and 50 controls with 35 women and 15 men (age range 18-82 years, mean $48.56 \pm 15.50)$. Of the 62 pemphigus patients, 57 (92\%) had pemphigus vulgaris, $2(3.2 \%)$ had pemphigus foliaceus, 2 (3.2\%) had pemphigus vegetans and 1 $(1.6 \%)$ had pemphigus erythematosus.

Anti-HCV Ab was negative in all of the pemphigus patients. Among this group, only one had a family member with $\mathrm{HCV}$ infection. In the control group, anti-HCV test results were found to be positive in $2(4 \%)$ individuals who were also positive for HCV-RNA, confirming HCV infection. We did not find a statistically significant difference between the two groups for HCV infection $(\mathrm{p}=0.114)$ (Table 1). In the assessment of risk factors, only one of the HCV- positive controls declared a past surgery, but that had been more than three months before and was not interpreted as a risk factor.

We could only evaluate HBV screening in 44 of the 62 pemphigus patients because of temporary technical problems. Fourteen $(31.8 \%)$ of the patients were $\mathrm{HBsAb}$ positive and $2(4.3 \%)$ were $\mathrm{HBs} A g$ positive, denoting HBV infection. We did not find any of the risk factors in the two pemphigus patients with Hepatitis B infection (Table 2). In the control group, 14 $(28 \%)$ individuals were $\mathrm{HBsAb}$ positive and $1(2 \%)$ was HBsAg positive. There were no statistically significant differences between the two groups for HBsAb and HBsAg positivity ( $\mathrm{p}=0.848, \mathrm{p}=0.526$, respectively) (See Table 1). We did not encounter any of the risk factors in the patients and controls with positive serology for HBV.

\section{DISCUSSION}

Pemphigus is an autoimmune disease characterized by painful oral mucosa erosions and fragile bullous skin lesions. The IgG-type antibodies targeting the keratinocytic antigens, desmoglein 1 and desmoglein 3, play a major role in the etiopathogenesis of the disease, by inducing acantholysis. ${ }^{12}$

Although there is some conflicting evidence, the hypothesis that some infections trigger autoimmune disease in genetically predisposed individuals is still up to date. The association of cryoblobulinemia and Sjögren syndrome with chronic HCV infections is well-known. Furthermore, the antinuclear, antismooth muscle, anticardiolipin and antithyroid antibody positivity accompanying these infections, support this view. ${ }^{4}$

The exact pathogenetic mechanism involved in $\mathrm{HCV}$ and autoimmunity is not known. However, this microorganism has been incriminated in the elimination of tolerance that is protected from autoimmunity. ${ }^{13}$ In addition, the activation of B lymphocytes resulting from $\mathrm{HCV}$ residence on these cells has been seen as responsible for autoimmunity. ${ }^{14}$

Some studies have investigated the association of $\mathrm{HCV}$ with autoimmune diseases. Agmon-Levin et al. found that the frequency of HCV infection in 1,322 patients with various autoimmune diseases was significantly higher $(8.7 \%)$, compared with the control group (\%0.4). In this study, the prevalence of $\mathrm{HCV}$ was found to be $14 \%$ among the pemphigus vulgaris patients, and the authors emphasized a new association between $\mathrm{HCV}$ and pemphigus. ${ }^{8}$ The prevalence of $\mathrm{HBV}$ infection in anti-HCV-positive pemphigus foliaceus patients was also found to be considerable. ${ }^{10}$ Sagi et al. found that the frequency of $\mathrm{HBV}, \mathrm{HCV}, \mathrm{H}$. pylori, T. gondii, T. pallidum and CMV was significantly higher than in the control group in pemphigus and 
TABLE 1: The comparison of HBsAg, Anti HBsAg and Anti-HCV test results and the existence of risk factors for hepatitis virus infections between the pemphigus group and the control group

\begin{tabular}{|c|c|c|c|c|c|c|c|c|}
\hline & & $\begin{array}{l}\text { Pemphigus } \\
\text { patients }\end{array}$ & $\mathrm{n}$ & $\%$ & $\begin{array}{l}\text { Control } \\
\text { group }\end{array}$ & $\mathbf{n}$ & $\%$ & $\mathbf{P}$ \\
\hline \multirow{2}{*}{\multicolumn{2}{|c|}{ Anti-HCV }} & Positive: & 0 & 0 & Positive: & 2 & 4 & 0.114 \\
\hline & & Negative: & 62 & 100 & Negative: & 48 & 96 & \\
\hline \multirow{2}{*}{\multicolumn{2}{|c|}{ HBsAg }} & Positive: & 2 & 4.56 & Positive: & 1 & 2 & 0.526 \\
\hline & & Negative: & 42 & 95.44 & Negative: & 49 & 98 & \\
\hline \multirow{2}{*}{\multicolumn{2}{|c|}{ AntiHBsAg }} & Positive: & 14 & 31.8 & Positive: & 14 & 28 & 0.848 \\
\hline & & Negative: & 30 & 68.2 & Negative: & 36 & 72 & \\
\hline \multirow[t]{16}{*}{ Risk Factors } & \multirow{2}{*}{$\begin{array}{l}\text { Abnormality in hepatic } \\
\text { function tests }\end{array}$} & Yes: & 2 & 3.2 & Yes: & 3 & 6 & 0.932 \\
\hline & & No: & 60 & 96.8 & No: & 47 & 94 & \\
\hline & \multirow{2}{*}{$\begin{array}{l}\text { Hepatitis B and/ } \\
\text { or C virus infection } \\
\text { in family members }\end{array}$} & Yes: & 1 & 1.6 & Yes: & 0 & 0 & 0.159 \\
\hline & & No: & 61 & 98.4 & No: & 50 & 100 & \\
\hline & \multirow{2}{*}{$\begin{array}{l}\text { Past operation } \\
\text { (operations done } \\
\text { under local or general } \\
\text { anesthesia) }\end{array}$} & Yes: & 14 & 22.6 & Yes: & 10 & 20 & 0.960 \\
\hline & & No: & 48 & 77.4 & No: & 40 & 80 & \\
\hline & \multirow[t]{2}{*}{ Ear piercing } & Yes: & 11 & 17,75 & Yes: & 13 & 26 & 0.294 \\
\hline & & No: & 51 & 82,25 & No: & 37 & 76 & \\
\hline & \multirow[t]{2}{*}{ Blood transfusion } & Yes: & 2 & 3.2 & Yes: & 1 & 2 & 0,381 \\
\hline & & No: & 60 & 96.8 & No: & 49 & 98 & \\
\hline & \multirow[t]{2}{*}{ Hemodialysis } & Yes: & 0 & 0 & Yes: & 0 & 0 & 1 \\
\hline & & No: & 62 & 100 & No: & 50 & 100 & \\
\hline & \multirow[t]{2}{*}{ Transplantation } & Yes: & 0 & 0 & Yes: & 0 & 0 & 1 \\
\hline & & No: & 62 & 100 & No: & 50 & 100 & \\
\hline & \multirow{2}{*}{$\begin{array}{l}\text { Blood transfusion or } \\
\text { past operation in the } \\
\text { last } 3 \text { months }\end{array}$} & Yes: & 0 & 0 & Yes: & 0 & 0 & 1 \\
\hline & & No: & 62 & 100 & No: & 50 & 100 & \\
\hline
\end{tabular}

TABLE 2: There were no risk factors in the two pemphigus patients with Hepatitis B infection

\begin{tabular}{llll}
\hline & & Patient 1 & Patient 2 \\
\hline Risk factors & Hepatitis B infection in family members & Absent & Absent \\
& $\begin{array}{l}\text { Past operation (operations done under local } \\
\text { or general anesthesia) }\end{array}$ & Absent & Absent \\
Ear piercing & Absent & Absent \\
Blood transfusion & Absent & Absent \\
Hemodialysis & Absent & Absent \\
Transplantation & Absent & Absent \\
Blood transfusion or past operation in the last 3 months & Absent & Absent \\
\hline
\end{tabular}


bullous pemphigoid patients. ${ }^{9}$ In accordance with these results, a pemphigus case has been reported after a hepatitis B vaccination. ${ }^{11}$ However, there are also opposing results: Rosa et al. did not find any association between $\mathrm{HCV}$ infection and pemphigus in 126 patients with fogo selvage, in their study group. ${ }^{10}$ In terms of our findings, although the prevalence of $\mathrm{HCV}$ infection was $4 \%$ in the control group, none of our 62 pemphigus patients had $\mathrm{HCV}$ infection. Nevertheless, the prevalence of HBV infection in our pemphigus patients was $4.3 \%$, while it was $2 \%$ in the control group. There was no statistically significant difference between the two groups for HBV and HCV infections. According to the surveys, $1 \%$ of the Turkish population has been found to be infected by $\mathrm{HCV}$, and
$2.7 \%$ by HBV. ${ }^{15}$ The results are also slightly different from the general population. We believe that the results obtained may have been caused by the small numbers in our study groups. If the number of patients and controls were higher, the prevalence of these viral infections would probably be closer to the prevalence within the general population.

\section{CONCLUSION}

The controversy surrounding the role of viral infections in the etiopathogenesis of autoimmune diseases still exists today. However, the findings of our study do not support any association between pemphigus and HBV and/or HCV infections.

\section{REFERENCES}

1. Miller SD, Katz-Levy Y, Neville KL, Vanderlugt CL. Virus-induced autoimmunity: epitope spreading to myelin autoepitopes in Theiler's virus infection of the central nervous system. Adv Virus Res. 2001;56:199-217.

2. Sagi $L$, Sherer $Y$, Trau $H$, Shoenfeld $Y$. Pemphigus and infectious agentes. Autoimmun Rev. 2008;8:33-5.

3. Harada M, Fujisawa Y, Sakisaka S, Kawaguchi T, Taniguchi E, Sakamoto M, et al. High prevalence of anticardiolipin antibodies in hepatitis $C$ virus infection: lack of effects on thrombocytopenia and thrombotic complications. J Gastroenterol. 2000;35:272-7.

4. Jadali Z, Alavian SM. Autoimmune Diseases $C_{0}$-Existing with Hepatitis C Virus Infection. Iran J Allergy Asthma Immunol. 2010;9:191-206.

5. Halota W, Muszynska M, Pawlowska M. Hepatitis B virus serologic markers and antihepatitis B vaccination in patients with diabetes. Med Sci Monit. 2002;8:CR516-9.

6. Guillevin L, Mahr A, Callard P, Godmer P, Pagnoux C, Leray E, et al. Hepatitis B virusassociated polyarteritis nodosa: clinical characteristics, outcome, and impact of treatment in 115 patients. Medicine (Baltimore). 2005:84:313-22.

7. Soylu S, Gül U, Gönül M, Kiliç A, Cakmak SK, Demiriz M. An uncommon presentation of the co-existence of morphea and vitiligo in a patient with chronic hepatitis B virus infection: is there a possible association with autoimmunity? Am J Clin Dermatol. 2009;10:336-8

8. Agmon-Levin N, Ram M, Barzilai 0, Porat-Katz BS, Parikman R, Selmi C, et al Prevalence of hepatitis $\mathrm{C}$ serum antibody in autoimmune diseases. J Autoimmun. 2009:32:261-6

9. Sagi L, Baum S, Agmon-Levin N, Sherer Y, Katz BS, Barzilai O, et al. Autoimmune bullous diseases the spectrum of infectious agent antibodies and review of the literature. Autoimmun Rev. 2011;10:527-35.
10. Rosa H, Martins R, Vanderborght B. Hepatitis C virus investigation in pemfigus foliaceus (fogo selvagem) patients. Arq Gastroenterol. 2000;37:42-3.

11. Berkun $Y$, Mimouni D, Shoenfeld Y. Pemphigus following hepatitis B vaccination-coincidence or causality? Autoimmunity. 2005;38:117-9.

12. Karıncaoğlu Y. Pemfigus: epidemiyoloji ve patogenez. Türkderm 2008;42:1-4

13. Bach JF. Infections and autoimmune diseases. J Autoimmun. 2005;25:74-80.

14. Soylu S, Gül Ü, Kiliç A. Cutaneous manifestations in patients positive for anti-hepatitis C virus antibodies. Acta Derm Venereol. 2007;87:49-53.

15. Tozun N, Ozdogan OC, Cakaloglu Y, Idilman R, Karasu Z, Akarca US, et al. A nationwide prevalence study and risk factors for hepatitis A, B, C and D infections in Turkey. Hepatology. 2010;52:697A.

MAILING ADDRESS:

Gulsen Tukenmez Demirci

Başkent Üniversitesi İstanbul Sağlık Uygulama

Ve Araştırma Hastanesi

Mahir $\dot{I}_{z}$ Cad. No 4334662

Altunizade/istanbul. Turkey

E-mail: gulsentukenmez@yahoo.com

How to cite this article: Demirci GT, Aydingoz IE, Mansur AT, Atis G, Altunay IK. Hepatitis C and hepatitis B virus infections in the etiopathogenesis of pemphigus. An Bras Dermatol. 2014;89(3):423-6. 